\title{
1. The idea of economic growth
}

Before the Enlightenment era there was little or no concept of progress. Over the short historical period since then Western culture has come to be built on the taken for granted conviction that technical and social progress is not only possible and normal, but potentially limitless. Economists have probably done most to reinforce the faith through making economic growth the supreme and unquestionable goal of national and global economic policy. (Trainer 2014, p. 168)

It is hard to imagine a time when economic growth was not paramount in the minds of politicians, the media, business, trade unions, and the public at large. For years Statistics Canada, Canada's world-class statistical agency, published annual estimates of Canada's gross domestic product (GDP). Then it started producing quarterly estimates and now it releases estimates each month; such is the appetite for information about Canada's economy. As in so many countries, the statistical news is spread in print and electronically by newspapers, TV, radio, the Internet and by banks and investment houses. The latest estimates of GDP are compared with previous ones. The greater the increase, the better. Or is it?

Comparisons with other countries of GDP, GDP per capita, and growth rates are also popular and made easier through the widely accessible databases of international organizations such as the World Bank and the OECD. A ready audience can always be found for anyone who expresses concern about threats to their country's position in the international GDP league tables. We are told to spend more on education to prepare employees for the 'new economy' (a term that quickly became old after the dotcom crash of the late 1990s), or 'knowledge-based' economy (as if the 'old' economy ran without knowledge). We need to reduce taxes, increase subsidies for research and development, raise productivity, promote innovation, expand trade and attract foreign investment, all in pursuit of economic growth. And when it comes to immigration, let's encourage those with marketable skills and capital. Even our universities are expected to promote commercialization through teaching and research (Fallis 2007). And if governments lose the confidence of the electorate in their ability to promote economic growth they risk being replaced by another party which claims it can do better. ${ }^{1}$

In fact, however, economic growth has only been an explicit objective of government policy since the middle of the 20th century. The history 
of the idea of economic growth has been succinctly told by H.W. Arndt in The Rise and Fall of Economic Growth (Arndt 1978) and more recently by Schmelzer (2016) and Timmerman (2017). To understand the ascent of economic growth to the summit of government policy objectives we must first examine the birth of an idea that is even more fundamental in our culture than economic growth. This is the idea of progress. A belief in progress is one of the most important defining values of Western civilization, along with private property, respect for human rights, individual liberty, separation of church and state, representative democracy and the rule of law. These were the beliefs and principles established during the European Enlightenment of the 17th and 18th centuries by people such as Locke in England, Voltaire in France, Hume in Scotland, Lessing in Germany and Paine in what became the United States. The list of influential Enlightenment philosophers and writers is much longer than this but these five show the international character of the movement that bequeathed so many of the main beliefs and principles adopted by liberal democracies around the world. Central among these beliefs is a commitment to progress, to economic progress in particular, and more specifically to economic growth. Thus, the belief in economic growth as a necessary and desirable feature of modern societies reflects an even deeper commitment to the idea of progress. But where did this idea come from, on what is it based, and how well are its several dimensions captured in the pursuit of economic growth? We must answer these questions before we look at managing without growth.

\subsection{THE IDEA OF PROGRESS}

The first thing to understand about progress is that it is an idea. It assumes a past and presumes a future. The idea of progress as applied to human affairs is that events are sequential in the sense that one event succeeds another in a causal, not random manner. The idea of progress also entails the belief that the sequence of events has led and will continue to lead to improvement. Events that repeat themselves in a cyclical pattern would not be considered progress. Sequential events leading to a worsening situation would not be considered progress. It is a combination of sequential events leading, in some sense, to improvement that defines progress (Pollard 1971).

As far as we know from oral, written and pictorial records, belief in the idea of progress that we take for granted is at odds with what people believed throughout all but the last moments of human history. Until the Enlightenment, if people thought about it at all, most believed either that 
life was lived pretty much as it always had been, as in traditional societies, or that humanity was on a downward path, descending from a previous Golden Age or Garden of Eden. Redemption, if it was ever to come, would have to wait until the afterlife.

These views did not necessarily mean belief in a static, unchanging world. The seasons in which birth, growth, decline and death repeated themselves provided obvious signs of change, but change without direction. A belief in larger cycles involving rebirth and reincarnation as propounded in Buddhism and Hinduism entailed a belief in change but change described as much by repetition and decline as by novelty and improvement. (See Timmerman 2017 for an account of the deep historical and religious roots of the idea of growth.)

The belief that events are not necessarily a repeat of what has come before and that change for the better is not only possible but observable and achievable by human action, is a very modern idea. Indeed it is the quintessential modern idea. It is modernity. It is the idea that history has a direction and that the direction is towards improvement of the human condition. It is the idea of progress.

Sydney Pollard (1971, p. 20) tells us that the idea of progress is only about 350 years old. He explains that the idea emerged in Western Europe in the 16th and 17th centuries from two sources. The first was the rise of science as a deliberate effort by some individuals to learn from experience and to build on the previous work of others. The practice of science was and is all about the accumulation of knowledge based on a mix of hypothesis, experiment, and observation. It also involves sharing results with others through publication for corroboration, refutation and further development. Scientists as great as Newton were aware of how much they were indebted to others who had gone before. 'If I have seen further, it is by standing on the shoulders of giants' (Moncur 2007: Newton in a letter to Robert Hooke, 5 February 1675).

Science has direction. It is a systematic process of knowledge accumulation and it yields results considered to represent an improvement in understanding. In the 16th and 17th centuries and even later, science was practiced by a very small number of people who were not necessarily even identified as scientists. Most people knew nothing of what these early scientists were up to. Literacy rates were low, schooling was only available to the wealthy and paid far more attention to Greek and Roman writers of antiquity than to contemporary developments in science.

Initially it was only within the intelligentsia that science began to influence the way people thought about change in society. In Britain for example, the Royal Society was officially founded in 1660 at Gresham College, following a lecture by Christopher Wren. It grew out of meetings 
that began in the mid-1640s of a group of natural philosophers who gathered to discuss the ideas of Francis Bacon, famous for his influential essays on the philosophy of science. To this day, the Royal Society remains the pre-eminent 'independent scientific academy of the UK dedicated to promoting excellence in science' (Royal Society 2007). Similar organizations developed in other Western European countries around the same time or shortly thereafter, many of which are still flourishing. And the Royal Society spawned similar organizations in ex-British colonies, so there are Royal Societies in Australia, Canada and South Africa. All of these organizations continue to play an important role in promoting the practice of science and in supporting technological change and public policy across an ever-widening range of fields.

The rise of science and the propagation of a scientific way of thinking was a slow process, one which would have taken much longer to influence how people think about the world were it not for other changes that were under way at the same time. Equally if not more important in the early development of the idea of progress was the fact that people in several European countries began to experience positive changes in their own lives. They began to realize that their lives might be a little better than those of their parents, and that their children's lives might be even better than theirs. Gradually, the idea began to grow that this kind of improvement from one generation to the next might be part of a larger process of change that came to be referred to as progress.

These two forces, the emergence of science and the experience of improvements in living standards over a lifetime were not sufficient, according to Pollard, to account for the widespread acceptance of the idea of progress. He argues that science did not emerge on its own but in concert with the gradual development of entrepreneurship, early capitalism and new technologies, all of which prepared people's minds to accept the idea of progress. 'Such men as Bacon, Rabelais, Le Roy or Bodin caught their first glimpses of the idea of progress when they observed the tangible proofs of compasses, printing, gunpowder, and the other by-products of the capitalist expansion of their day' (Pollard 1971, p. 29).

In his account of the idea of progress, Pollard notes that in the 18th century, the century of the Enlightenment, there was a marked distinction in the scope of discussions about progress in post-civil war Britain and pre-revolutionary continental Europe. Following the victory of the parliamentarians over the monarchy in England in the late 17th century, British philosophers accepted the basic structure of society. As a result, they concentrated much of their attention on progress as economic growth. They accepted the system, now they wanted to know what made it run and 
how to make it run faster. This was embodied in the rise of British political economy led in particular by Adam Smith.

With Adam Smith we reach the parting of the ways. Henceforth, the unity of social philosophy is broken. British political economy (in due course to become 'economics') has taken off on a course of its own, manipulating with growing skill increasingly mobile variables within an increasingly rigid social framework ... the link with history has disappeared. (Pollard 1971, p. 77)

Pollard contrasts the British approach to political economy and progress with that of Voltaire, 'the most influential single individual of the Enlightenment' (Pollard 1971, p.53). Like so many other philosophers writing about progress in pre-revolutionary France, Voltaire stressed the structural changes in society required for continued social and economic progress. This difference between British and continental European writers in the 18th century anticipated the 20th-century distinction between growth and development. Nowadays growth is defined as increases in economic output within given institutional structures whereas development refers to a broader set of institutional changes as a precondition for ongoing increases in economic output. 'Because the realization of economic opportunities also depends on political liberties, the term "development" has increasingly encompassed political development as well as economic development' (Meier 2005, p. 6).

Another feature of the idea of progress that became generally accepted by 18 th-century writers was that progress was not just about progress in science and technology. It also included 'progress in wealth, in civilization, in social organization, in art and literature, even in human nature and biological make-up' (Pollard 1971, p.31). In their eyes, progress meant much more than economic growth. It meant improvement in all facets of individual and social experiences. As we shall see, such a broad conception of progress encompassing improvement in all aspects of the lives of individuals and communities has been severely curtailed as the idea of progress evolved from its historically broad origins to the narrower conception of progress as economic growth.

By the 19th century the idea of progress had become established not only in the minds of scientists, philosophers, politicians and educated people in general, but also in the minds of ordinary people, educated or not. It started in Britain, Western Europe, the United States, Canada and Australia and began spreading around the world. Much of 19th-century literature that dealt with the idea of progress was written by historians and others who sought to describe the transition of societies from one stage to the next in a fixed sequence. This idea was especially popular among the German historical school. 'According to them, history proceeded in stages, 
each of which had a recognisable character of its own, determining all facets of society, including its economic relationships, and each, by its own immanent constitution, inevitably prepared the way for and ushered in the next' (Pollard 1971, p. 136). Similar ideas, though with a more restricted focus, were popularized in the 1960 s by W.W. Rostow in his influential book The Stages of Economic Growth (Rostow 1960).

In the 20th century, the idea of progress was fully accepted by mainstream society. There were still commentators who were pessimistic about the long-term prospects for progress but even Karl Marx, who had argued that capitalism contained the seeds of its own destruction, believed that a better world would emerge from its ashes. A growing majority of others were far more optimistic. Despite the failures of Western civilization - two World Wars, the Great Depression of the 1930s, the Holocaust, the Cold War - and the intellectual challenge from post-modernism, this optimism about the inevitability of progress continues into the 21 st century though perhaps with less enthusiasm. Now few people, especially in rich countries, question the idea of progress.

\subsection{ECONOMIC GROWTH AS PROGRESS}

To say that we manage what we measure has become a cliché, but it is a useful one nonetheless. For societies that believe in progress based on science and technology, it is to be expected that they would develop ways of measuring it. In a world that seems overflowing with statistics, the one that is most highly favored over all others as a measure of progress is Gross Domestic Product (GDP). GDP can be measured in three equivalent ways. It is:

(1) an aggregate measure of production equal to the sum of the gross values added of all resident institutional units engaged in production (plus any taxes, and minus any subsidies, on products not included in the value of their outputs);

(2) the sum of the final uses of goods and services (all uses except intermediate consumption) measured in purchasers' prices, less the value of imports of goods and services; and (3) the sum of primary incomes distributed by resident producer units. (OECD 2001)

As economic growth became virtually synonymous with progress, increases in GDP became our main measure of progress.

While the level of GDP per head of population is the most commonly used shorthand measurement of the economic well-being of a given country (most of all in international comparisons), its variation over time in real terms (in 
other words at constant prices) measures economic growth, the maximisation of which is usually considered to be the main goal of economic policy. (Giovanni 2008, p. 13)

If we understand progress to mean an improvement in well-being then GDP is a poor measure. American economist Simon Kuznets was one of the main architects of the system of national income accounts from which GDP is obtained. When he appeared before the US Congress in 1934 he said the 'welfare of a nation can scarcely be inferred from a measurement of national income' (Kuznets 1934). However, as history has shown, his warning went unheeded. GDP includes many items that grow when things are or might be getting worse: for example, household expenditures on health care, repairs, commuting, pollution control devices, home security measures. It includes government expenditures on police and defense. Equally problematic as a measure of progress in terms of well-being is what is left out of GDP: voluntary work, unpaid housework, leisure time, illegal trades, capital depreciation, damage to the environment and the depletion of natural resources. Obviously GDP is not a reliable indicator of progress (Eisner 1994, Chapter 2; The Economist 2016).

GDP also tells us nothing about how the output of goods and services is distributed among the members of society. A growing GDP that is increasingly unequally distributed is a poor indicator of progress. Complementary statistics such as the Gini coefficient, which is a measure of distribution, can help but they are seldom produced and publicized with the same frequency. Rising GDP per capita improves upon GDP in one respect. It recognizes that the size of the population among whom an increase in GDP is shared affects the average amount of goods and services available to each person. Japan is an example of a country in which the rate of economic growth has declined from world-leading levels of 6 or more percent after World War II to around 2 percent or less since 1990. Yet the effects have been tempered by a declining rate of growth in the population, becoming negative in 2011, such that GDP per capita has continued to rise at a modest rate (World Bank 2016c). But since GDP per capita is a measure of the average GDP per person and not of its distribution, this fundamental deficiency of GDP as a measure of well-being remains.

Despite these well-known deficiencies of GDP as a measure of wellbeing it continues to reign supreme as a measure of progress. Consider this claim by the Commission on Growth and Development:

A growing GDP is evidence of a society getting its collective act together. As its economy grows, a society becomes more tightly organized, more densely interwoven. A growing economy is one in which energies are better directed; resources better deployed; techniques mastered, then advanced .... Growth is 
not an end in itself . . . but growth is a necessary, if not sufficient, condition for broader development, enlarging the scope for individuals to be productive and creative. (Commission on Growth and Development 2008, pp. 17, 1)

Significantly, the Commission acknowledges that 'accelerated growth has created new challenges ... a clear divergence in incomes within and between countries ... and new pressure on the planet's ecology and climate' (Commission on Growth and Development 2008, p. 19), but does not see them, especially the pressure on the planet, as being a problem that cannot be addressed by further growth in GDP. And the Commission, whose main purpose was to share its understanding of the experience of growth and development with political leaders and policy makers in developing countries, fails to connect ongoing economic growth in advanced economies with diminished prospects for growth in poorer ones.

One prominent politician who had an excellent grasp of the limitations of GDP as a measure of progress is Robert Kennedy, who in a speech in 1968 at the University of Kansas (Kennedy 1968) said about gross national product: ${ }^{2}$

Too much and too long, we seem to have surrendered community excellence and community values in the mere accumulation of material things. Our gross national product ... if we should judge America by that - counts air pollution and cigarette advertising, and ambulances to clear our highways of carnage. It counts special locks for our doors and the jails for those who break them. It counts the destruction of our redwoods and the loss of our natural wonder in chaotic sprawl. It counts napalm and the cost of a nuclear warhead, and armored cars for police who fight riots in our streets. It counts Whitman's rifle and Speck's knife, and the television programs which glorify violence in order to sell toys to our children.

Yet the gross national product does not allow for the health of our children, the quality of their education, or the joy of their play. It does not include the beauty of our poetry or the strength of our marriages; the intelligence of our public debate or the integrity of our public officials. It measures neither our wit nor our courage; neither our wisdom nor our learning; neither our compassion nor our devotion to our country; it measures everything, in short, except that which makes life worthwhile.

We are so accustomed to hearing about economic growth and about what governments are doing to promote it, that we might think that governments have always taken responsibility for economic growth. This would be a mistake. National income accounting began in earnest in the USA and other countries during the economic depression of the 1930s. It received impetus from World War II. Knowledge of how much could be produced in economies working flat out was regarded as critical information for the conduct of the war especially by the Allies. This is when the 
expenditure estimates of GDP began to be produced systematically and regularly (Carson 1975).

Those charged with responsibility for measuring economic output did not have to start from scratch. William Petty (1623-87) estimated the national income of England through what he termed 'political arithmetick' (Petty 1691). Subsequently many scholars have considered the definition and measurement of the output of an economy and some made their own estimates. However, it was only when the measurement of national economic output, both actual and potential, became important for government policy that adequately standardized conventions, methods and data were developed. This started in the 1930s with contributions from many economists and statisticians (Bowley 1942) and continues to this day, led by the United Nations which has established the System of National Accounts for all countries to follow (United Nations et al. 2009).

As World War II drew to a close, governments in North America, Western Europe, Australia and New Zealand became concerned about the possibility of recession and high unemployment, even a return of the Great Depression of the 1930s. When literally millions of de-mobbed soldiers started looking for work, where would they find it? Fortunately there was now an answer based on the work of John Maynard Keynes, the most influential economist of the 20th century.

\subsection{KEYNESIANISM, GDP AND FULL EMPLOYMENT}

In his General Theory of Employment, Interest and Money (Keynes 1935) Keynes argued that the private sector, if left to itself, could settle on a level of economic activity far below the productive potential of an economy, resulting in very substantial unemployment. He found no automatic mechanism that guaranteed a level of total expenditure sufficient to employ all those who wished to work. He rejected the argument of what was then mainstream economics that unemployment resulted from wage levels that were too high and that a reduction of wages, resisted by unions, would entice employers to hire more people. On the contrary, Keynes argued that lower wages would mean less spending and even more unemployment as employers cut back production still further. Unemployment, Keynes argued, was a macroeconomic problem rather than a microeconomic one, a problem of the economy as a whole, a problem of a lack of aggregate demand, a problem then of inadequate GDP.

Keynes further distanced himself from the mainstream by arguing that if governments used their powers of expenditure and taxation appropri- 
ately, they could regulate the level of aggregate demand (the total level of spending in the economy), so that unemployment could be reduced to very low levels if not eradicated entirely. Keynes was aware of the risks of price inflation if aggregate demand was raised to a level in excess of the productive capacity of the economy. It would be the task of government to steer a course between total expenditures that were too little and too much.

The basic Keynesian message was that in the face of too much unemployment governments should spend more than they receive in taxes to stimulate the economy, and in the face of inflationary pressures, they should do the opposite. Over time, the ensuing budget surpluses (when expenditures minus tax revenues are positive) and deficits (when expenditures minus taxes are negative) would even out so that the national debt would remain relatively stable. Well, that was the theory. Its endorsement by many economists and politicians in the 1940s and 1950s allowed governments in most Western countries to take responsibility for full employment. That these countries had experienced full employment during the war when government expenditures had been running at record levels was all the proof they needed that Keynes was right.

The report by William Beveridge, Full Employment in a Free Society (Beveridge 1945) was very effective in transmitting Keynes's explanation of the causes of unemployment and its remedy. Paul Samuelson's highly successful textbook Economics, first published in 1948, and now in its 19th edition translated into 41 languages, also played a key role in spreading Keynesian ideas among generations of students. Britain's wartime coalition government committed itself to full employment using Keynesian methods. At about the same time the Australian government made a similar commitment, followed closely by the Canadian government in a White Paper in 1945 and the government of the USA, with some reservations, through the Employment Act of 1946. Full employment was also incorporated in the United Nations Charter (Arndt 1978, pp. 27, 28; Gross 1987).

It is important to note that before the advent of Keynesianism, it was widely believed that governments could help create the conditions for a well-functioning economy, but they could do very little directly to reduce unemployment. Typically, this meant limiting monopoly power, including that of trade unions, reducing tariffs, guaranteeing the right of private property, and keeping taxes and interest rates low. It might also include public education to secure a trained and capable work force. These policies had failed to ensure full employment or anything close to it for years, even decades, at a time, but they were the best available until Keynes came along. What was new after World War II was that governments believed they now had the tools with which to manage the economy and to ensure 
that it operated at or near full employment year after year, and for some 25 years they were not wrong. From 1960 to 1972 unemployment rates in OECD countries stayed well below 6 percent (Nickell et al. 2005, Table 1), in large measure due to the deliberate intervention of governments acting on Keynesian principles.

It was not until the early to mid-1970s that the Keynesian formula was found wanting. The new problem was 'stagflation', the simultaneous occurrence of economic stagnation (unemployment) and inflation following the rapid rise in oil prices in the 1970s. This was the time when monetarism began to flourish, first in academic circles led most notably by Milton Friedman in the USA and then adopted by governments who believed that control of the money supply, defined in various ways, and fiscal prudence were the order of the day. Keynesian policies did not provide an answer to stagflation but neither did monetarism (Allen and Rosenbluth 1992). The application of monetarist policies coupled with fiscal restraint and a call for balanced budgets reached its zenith in the 1990s. Canada was among the leaders of this movement, which achieved 10 consecutive budgetary surpluses between 1997 and 2007 (Statistics Canada 2016d). But even though there is still considerable enthusiasm for balanced budgets in some quarters (for example Speer and Emes 2014; Mitchell 2011; 2014) the gilt is off the monetarist lily. Macroeconomic policy has become more pragmatic and less obviously ideological. Central banks use the interest rate on overnight loans to the commercial banks to influence interest rates throughout the economy, lending by the commercial banks and hence the money supply. The primary objective of central banks is to keep inflation low while departments of finance implement fiscal policies governing taxation and expenditure broadly speaking along Keynesian lines, though with the 'non accelerating inflation rate of unemployment' (NAIRU) as their target rather than full employment. (See Chapter 10 for more discussion of NAIRU, inflation targeting and full employment.)

\subsection{FROM FULL EMPLOYMENT TO ECONOMIC GROWTH}

Keynes is famous for saying that his was a short run theory because 'in the long run we are all dead.' (This phrase comes from his earlier book $A$ Tract on Monetary Reform (Keynes 1923, p. 80) but it also characterized his more famous General Theory.) One feature that made his a short-run theory was that he included investment (that is, expenditures on new infrastructure, buildings and equipment) as a component of aggregate demand without much concern with the fact that these expenditures also increase the 
productive capacity of the economy. When Keynes was writing and until quite recently, more investment meant more factories with more machines requiring more workers from an expanding labor force. Nowadays it might also mean more software, more computing power, more artificial intelligence and a requirement for fewer employees. The potential for capital investment to displace human workers did not go unnoticed by Keynes. Indeed he thought it offered the promise of a much better future with a much shorter work week (Keynes 1930[1963]), but it is one that has yet to materialize, a topic to which we return in Chapters 11 and 12.

In the General Theory, Keynes was primarily concerned with how governments could use their taxation and spending powers to achieve full employment. He saw that the key to this was for government to directly influence the level of aggregate expenditures in the economy such that it was sufficient for full employment. But this level of expenditure and the output to which it corresponds has to increase year over year in step with the increase in productive capacity to maintain full employment. Failing this, it would take fewer and fewer employees to produce an unchanging output unless working hours are reduced. This 'productivity trap' represents a significant threat to full employment in the absence of economic growth (Jackson and Victor 2011). The ongoing impact of rising labor productivity on employment as capital displaces labor explains why communities and the politicians that represent them celebrate the construction of a new factory not so much for the increase in supply of some needed product, but because of the jobs it creates. In advanced economies, the shortage of employment has become more important than the shortage of products. This is clear from media accounts of new production lines at car assembly plants that announce the number of new jobs, not new cars. It's as if the cars produce jobs rather than the other way around. In the past we needed more people at work because we needed the goods and services they produce. Now we have to keep increasing production simply to keep people employed so that they can earn an income and buy the goods and services they need and want. What was a problem of production has become a problem of distribution. If we are to manage without growth then we must find a way of overcoming this problem, and in Chapters 11 and 12 we will see how this can be done.

Keynes left it to others to work out the relationship between full employment and economic growth. This was the issue taken up in 1939 by R. Harrod in Britain and in 1946 by E. Domar in the USA, leading to the Harrod-Domar model of economic growth, as well as by other notable economists heavily influenced by Keynes. The Harrod-Domar model examined the conditions necessary for balanced growth in aggregate demand and productive capacity. It influenced much of the subsequent work by economists on the theory of economic growth. 
A few years after governments committed themselves to the maintenance of full employment, they adopted economic growth as a policy objective. Domar stated that his and Harrod's work was 'concerned with unemployment and treated growth as a remedy for it rather than an end in itself' (quoted in Arndt 1978, p. 33). Arndt observed that 'there is in fact hardly a trace of interest in economic growth as a policy objective in the official or professional literature of western countries before 1950' (1978, p. 30). In 1936, Colin Clark published the first ever estimates of the annual rate of growth of real income per person (Arndt 1978, p. 32). 'The first annual Economic Survey for the United Kingdom in which the term "rate of growth" occurs was that for 1950' (Arndt 1978, p. 32). Referring to a statement by the US Council of Economic Advisors in October 1949, Arndt says 'it was perhaps the first explicit official pronouncement in favour of economic growth as a policy objective in any western country' (1978, p. 37).

How quickly things changed. By the end of the 1950s economic growth had been 'thrust to the top as apparently the supreme, overriding objective of policy' (Arndt 1978, p. 41). In analyzing the rapid ascent of economic growth atop the list of government policy objectives Arndt notes that 'more rapid economic growth came to be regarded as a prophylactic or remedy for all the major current ailments of western economies - balance of payments difficulties and especially dollar shortage, underemployment, and inflation whether due to excess demand or competing income claims' (1978, p. 43). In the USA, Arndt adds the Soviet challenge and the Cold War as another important reason why economic growth attained top priority. 'In the 1950s momentous political importance came increasingly to be attached to international comparisons of growth rates ... The first UN Economic Survey of Europe to present growth rates of real GDP, based on the OECD estimates, was that of $1957^{\prime}$ (1978, pp. 50, 51).

Why growth rates differ became a topic of intensive academic research in the early 1960s and 'from that year [1960], for a decade, economic growth occupied an exalted position in the hierarchy of goals of government policy both in the United States and abroad' (Arndt 1978, p.55). Economic growth was a major campaign issue in the celebrated contest between Kennedy and Nixon. When Kennedy became President, faster economic growth became a central objective (Arndt 1978, pp. 55, 56).

The UN World Economic Survey 1959 stated 'The reinterpretation of the objective of full employment under the United Nations Charter to embrace the goal of economic growth marks a second fundamental change in public policy thinking' (quoted in Arndt 1978, p. 62). 'Not only France and Britain, Sweden and the Netherlands, but also Germany, Belgium 
and Switzerland which had remained the citadels of non-interventionist policies ... took in the sixties [steps] towards a more purposeful control of economic growth' (Arndt 1978, pp. 63, 64).

By the end of the 1960s the case for economic growth as an overarching policy objective of governments in developed countries had matured. The fully fledged case for economic growth had many facets but as Arndt notes,

the belief that steadily, rapidly and (at least for the foreseeable future) indefinitely increasing productive capacity is an important policy objective even in the rich countries because higher living standards in the widest sense are desirable and demanded, undoubtedly constituted the core of the case for economic growth. (1978, p. 73)

Arndt based the case for economic growth in developed countries on five principles: the desire for continued material progress; the greater ease of dealing with competing claims when economic output is growing, making other problems such as achieving full employment more manageable; maintaining a 'cheerful state' in society; harking back to Adam Smith; and keeping up with others. In regard to this last principle Arndt quotes Domar, one of the fathers of modern growth theory who said that, in relation to international rivalry 'such motives have given rapid growth a status among the objectives of economic policy of the major (and even many minor) powers almost independent of rational assessment of benefits in terms of standard of living' (Arndt 1978, p. 76).

Recent research by Matthias Schmelzer (2016) has increased our understanding of the rise of the 'growth paradigm'. Schmelzer, an economic historian, defines the growth paradigm as 'a specific ensemble of societal, political, and academic discourses, theories, and statistical standards that jointly assert and justify the view that economic growth as conventionally defined is desirable, imperative, and essentially limitless' (2016, p. 264). In other words, the emergence of economic growth as the principal economic policy objective of so many governments was a reflection of a set of more deeply held beliefs. Based on an examination of early documents from the OECD and its forerunner, the Organization for European Economic Development, Schmelzer identifies four of these beliefs:

(1) that GDP . . . adequately measures economic activity; (2) that growth was a panacea for a multitude of . . . socio-economic challenges; (3) that growth was ... a necessary means to achieve some of the most essential societal goals such as progress, well-being, or national power; and (4) that growth was essentially unlimited, provided the correct ... policies were pursued. (Schmelzer 2016, p. 264) 
These beliefs were challenged at the time, with little or no effect (Schmelzer 2016, p.265), but they became the focus of a wide-ranging critique of economic growth that has fluctuated over the past half century and is gaining momentum today.

\subsection{ECONOMISTS QUESTION GROWTH}

When economic growth was reaching the pinnacle of policy objectives some dissenting voices were beginning to be heard. One of the most widely read was John Kenneth Galbraith. In The Affluent Society published in 1958 and revised through multiple editions, Galbraith compared private affluence in the USA with public squalor. He also questioned the efficacy of dealing with poverty through a general rise in incomes (Galbraith 1958). Many academic economists regarded Galbraith as more of a political commentator than a serious economist because of his disdain for theoretical economics, and on these tenuous grounds they resisted his arguments. The same could not be said of British economist Ezra Mishan who published The Costs of Economic Growth in 1967 (Mishan 1967). Mishan was a highly regarded and well-published expert in 'welfare economics', the field within mainstream economics that is concerned with the relationship between economic activity and well-being. So although Mishan's analysis of the costs of economic growth was aimed at a broad audience, no one could dismiss the author as not really understanding modern economic theory.

Perhaps this is one reason why Mishan's critique of economic growth, unlike Galbraith's, ignited a heated debate that went on for several years between him and Wilfred Beckerman, another well-established British economist. Beckerman wrote 'Why we need economic growth' (1971) and In Defence of Economic Growth (1974). Later Beckerman wrote Small is Stupid (1995) in response to Small is Beautiful, Schumacher's critique of modern industrialized economies (Schumacher 1973). Many of Schumacher's arguments about the optimal scale of an economy were anticipated, echoed and augmented by other economists notably Kenneth Boulding in his seminal essay 'The economics of the coming spaceship earth' (1966), Georgescu-Roegen in his path-breaking work on entropy and economics (1971; 1975), and Herman Daly in Steady-State Economics (1977) and many other writings. Meanwhile Beckerman continued to resist criticisms of economic growth (Beckerman 2003).

So, within a couple of decades of economic growth becoming the supreme policy objective of most if not all Western governments, serious concerns were being raised even from within the economics profession. 
The contemporaneous rise of modern environmentalism, largely a movement led by non-economists, buttressed the arguments of the economists challenging the growth paradigm, as did the widely read Limits to Growth (Meadows et al. 1972), which examined the implications of physical constraints on global economic growth. Fred Hirsch in The Social Limits to Growth (1976) used the concept of 'positional' goods to account for the disconnect between higher incomes and increases in well-being. We will examine arguments from this literature in later chapters.

Arndt titled his book The Rise and Fall of Economic Growth, which suggests that by the late 1970s he believed the critics of economic growth had managed to undermine its pre-eminence as a policy objective. This assessment was premature. The commitment to economic growth remains firmly entrenched as the number one priority of most governments today even though it may be promoted in the guise of free trade, competitiveness, productivity and the like or even as 'sustainable development'. Clearly Arndt himself was unconvinced by the critics of growth. His reasons are very similar to those still given for continuing the commitment to economic growth. That rich economies are already more than double their size when Arndt was writing in the 1970s seems not to matter when progress is at stake. Arndt expressed great faith in the price mechanism to handle scarcity. The standard argument is that if a resource becomes scarce its price will rise, providing incentives for further exploration, for extraction from sources not previously profitable, for the development of substitutes, for better technologies, and for more efficient resource utilization through better design, reuse and recycling. This is a well-established argument in the economics of environmental and natural resources (Tietenberg and Lewis 2014, Chapter 6). One limitation is that it only applies when property rights to resources are clearly established and enforceable in the courts, otherwise those who would respond to increasing scarcity by investing in more exploration and new technologies are discouraged from doing so because they cannot appropriate all the benefits. This is a very large problem especially with respect to many potentially renewable resources such as easily accessed forests, ocean fisheries, the atmosphere, and the gene pool.

Even with non-renewable resources prices may not give the right signals. The argument that prices will handle scarcity of these resources over time assumes that their owners and managers will behave in certain ways conducive to conservation rather than exploitation and this may not be the case. For example, if resource owners anticipate the development of a substitute for their increasingly scarce resource they may expect the price to go down when the substitute becomes available rather than up in response to increasing scarcity of the resource they own. With this expectation, to 
maximize their profits they will increase the rate of extraction, not reduce it, which, in the short term, will depress prices fulfilling their expectations of a price fall. Such behavior runs counter to price induced conservation. It is not far-fetched either. For example, maintaining the supply of oil so that increases in oil prices are moderated, reducing the incentive for the development of alternatives, can be in OPEC's interests. Indeed, this became the strategy adopted by some of its members, notably Saudi Arabia, in response to the increase in 'unconventional' oil coming from the USA made possible by new extraction technologies such as hydraulic fracturing (fracking) and horizontal drilling (Critchlow 2015; Bader 2015).

While prices can and do play a useful role in dealing with resource scarcity it would be foolhardy to rely on them too much, especially for resources where the conditions for a well-functioning market do not exist (see Chapter 3). And even where they do exist, market prices cannot signal anything participants in the market are not concerned about, such as declining supplies decades or centuries ahead.

Sometimes we get the impression that human-induced impacts on the global environment, such as climate change, have only recently been identified as serious. As we shall see in Chapter 5, this is far from true. Arndt was aware of large-scale environmental problems, noting that 'our ignorance about these matters is still great' (Arndt 1978, p. 144), but he was not particularly concerned about them, believing that 'on most of these dire predictions, of over-heating of the earth's atmosphere, destruction of the ionosphere and irremediable damage to ecological balance in other forms, the weight of reputable scientific opinion appears to have come down against the prophets of doom' (Arndt 1978). With all the evidence that has accumulated in the past four decades of climate change caused by human activities, depletion of the ozone layer from human-made CFCs, and the disturbing loss of habitat, species and biodiversity from the expanding presence of humanity on the globe, I doubt if he would hold the same opinion today. This evidence which informs the discussion in later chapters has been effectively summarized in the literature on 'planetary boundaries' (Rockström et al. 2009a, 2009b; Steffen et al. 2015b).

Arndt concludes with four prescient statements about the possibility and desirability of continued economic growth that resonate today and which, to a greater or lesser extent, are themes that will occupy us throughout the rest of this book:

[1.] there is little if any convincing scientific evidence that exhaustion of nonrenewable natural resources or irreversible damage to the biosphere will set early limits to growth, though it is possible, but by no means certain, that economic growth will be slowed down over the next century by rising long-run cost curves for some key resources, such as fossil fuels. 
[2.] as per capita income rises, the costs of economic growth tend to increase relative to its benefits.

[3.] there does not seem the least chance that people will voluntarily forgo opportunities for higher standards of living ... merely because enough is enough.

[4.] therefore the realistic question to ask is ... what kind of growth we should aim at. To have focused public attention on this question is the major achievement of the critique of economic growth of the past decade. (Arndt 1978, p. 150)

We shall return to these contentious conclusions quite often as we consider the prospects and promise of managing without growth.

\subsection{ECONOMIC GROWTH REMAINS PARAMOUNT}

Arndt's cogent account of the rise of economic growth as a policy objective was published three-quarters of the way through the 20th century. Throughout the remainder of the century and into this one, economic growth has maintained its position at or near the top of policy priorities in most countries. Economic growth in developing countries and countries in transition (the old eastern bloc) is important though it is doubtful whether the adoption of a development path that tries to mimic the experience of the rich countries by stressing growth over distribution is feasible and desirable. However, this book is not about developing countries or countries in transition except indirectly. The continued aggressive pursuit of growth by the rich countries has many negative implications for much poorer countries because of global limits on resources and the capacity of the biosphere to absorb and recycle wastes. Managing without growth in advanced economies has a lot to do with leaving room for those whose need is greatest.

With the benefit of hindsight, Arndt's conclusion that by the mid-1970s the commitment to economic growth as the number one policy objective of government had crested was premature. The Organisation for Economic Co-operation and Development (OECD) was founded in 1960 by 20 developed countries and now has 35 members. Article 1 (a) of the OECD charter states,

The aims of the Organisation for Economic Co-operation and Development ... shall be to promote policies designed to achieve the highest sustainable economic growth and employment and a rising standard of living in Member countries, while maintaining financial stability, and thus to contribute to the development of the world economy. (OECD 1960) 
The OECD continues to pursue growth with full vigor. In 2005, the OECD published Economic Policy Reforms: Going for Growth (OECD 2005). Donald Johnston, the OECD Secretary General, writes in the Foreword that: 'As policy makers and others grapple with the challenges posed by the increasing interdependence of our economies, growth has to be at the top of our agenda' (OECD 2005, p. 4). Since this first edition the OECD has published annual reports with the same title, giving advice to member governments on ways to promote economic growth. In the OECD, economic growth as a dominant objective of government policy is alive and well, albeit sometimes qualified as 'inclusive, sustainable growth' and 'green growth' (OECD 2014; 2015d). The insertion of these adjectives in front of growth is a welcome, if belated, recognition that the pursuit of economic growth per se is not necessarily inclusive, sustainable or green. Whether economic growth can be all of these things is what this book is about and if not, what the alternatives might look like.

This is not to deny that other policy objectives have taken center stage for a while. Objectives such as free trade, increased competitiveness, lower taxes, reducing governments' deficit, innovation, and higher productivity have all had their moments as the focus of government economic policy, but hardly as ends in themselves. They are all promoted as ways of securing increases in economic output; whether they do or not is another matter. The point is that they are best regarded as instrumental policies in the general pursuit of faster, more robust economic growth.

\subsection{SUSTAINABLE DEVELOPMENT - NEW WINE IN OLD BOTTLES}

In 1987, the UN World Environment Commission published the widely read report Our Common Future (World Commission on Environment and Development 1987), known as the Brundtland report, popularizing and promoting the concept of sustainable development. The subsequent commitment by many governments to sustainable development is best understood as more of the same rather than a radical departure from economic growth as the top economic policy objective. The absence of a completely unambiguous definition of sustainable development in the Brundtland report helped make it possible for governments, businesses and others to adopt the goal of sustainable development without compromising their adherence to economic growth. Now there are definitions and interpretations of sustainable development to suit everyone. Some of these place very heavy emphasis on economic growth. Only two years after publication of the Brundtland report, Pezzey listed over 60 definitions of 
sustainability from the literature. His catalogue of definitions includes six from the Brundtland report alone (Pezzey 1992).

Reflecting on the impact of the Brundtland report nearly 20 years after its publication, Jim MacNeill, one of its lead authors, commented that:

I also never thought that the concept of sustainable development could and would be interpreted in so many different ways . . . Many of them, of course, are totally self-serving. I no longer shock easily but to this day I remain stunned at what some governments in their legislation and some industries in their policies claim to be 'sustainable development.' Only in a Humpty Dumpty world of Orwellian doublespeak could the concept be read in the way some would suggest .... In 1987, we thought the concept was plain enough. We defined it in several ways - ethical, social, ecological . . Only one definition grabbed the headlines, however, and stuck, unfortunately to the exclusion of all the others. It's the one that features the need for intergenerational equity ... 'development which meets the needs and aspirations of the present generation without compromising the ability of future generations to meet their own needs'. (MacNeill 2006 pp. 3, 4)

Where does economic growth fit within the Brundtland report's definition of sustainable development? Clearly, it is not a repudiation of growth. 'We see . . . the possibility for a new era of economic growth, one that must be based on policies that sustain and expand the environmental resource base' (World Commission on Environment and Development 1987, p. 1). To be fair the main concern of the Commission was with the prospects and possibilities facing developing countries and the threats to their future presented by a wide range of environmental factors that are thoroughly discussed in the report. However, the Commission did not consider whether these countries might find it easier to develop if they were not facing such vigorous competition from rich countries in pursuit of their own economic growth.

In a comparison of conventional and alternative interpretations of sustainable development, David Korten writes that sustainable development as conventionally understood is about achieving the sustained economic growth needed to meet human needs, improve living standards, and provide the financial resources that make environmental protection possible' (Korten 1996). In other words, Korten observes that sustained economic growth is a fundamental component of sustainable development as conventionally understood without any differentiation between rich and poor countries.

A good example of this conventional understanding of sustainable development is provided by the Canadian Department of Finance which defined sustainable development as 'long-term sustainable economic growth based on environmentally sound policies and practices. Environmental 
degradation at the local, national and international level undermines prospects for continued economic development' (Department of Finance Canada 2007). Apparently in 2007 the Department of Finance believed that sustainable development is all about sustaining long-term economic growth and that environmental degradation matters because it undermines the growth process. In terms of whether sustainable development has supplanted in any meaningful way the commitment to economic growth, Canada's Department of Finance could not have been clearer: it had not. ${ }^{3}$

Subsequently, the Federal Government's Sustainable Development Office, established by an Act of Parliament in 2008, stated that 'the Government's Plan for Responsible Resource Development ... was designed to promote sustainable economic growth while introducing significant new measures to ensure environmental protection, and supporting social development ...' (Environment and Climate Change Canada 2013, p. 4, emphasis added). The emphasis on economic growth within the context of sustainable development was reaffirmed in the Federal Government's sustainable development strategy for Canada 2016-19 where the promotion of economic growth is prominent throughout the document, for example '. . . sustainable development means achieving lowcarbon, environmentally responsible economic growth ...' (Environment and Climate Change Canada 2016).

Further insight into how the Canadian Government understands sustainable development is provided by the following statement: 'Interconnections between the environment and the economy are evident in the federal government's efforts to support sustainable economic growth and responsible resource development - for example, by expanding Canada's international trade' (Environment and Climate Change Canada 2016, p. 8). Perhaps the most telling indication that sustainable development has done little to change government thinking about economic growth is provided by the Federal Government's budget for 2016 (Morneau 2016). In this fundamentally important statement of government priorities, 'economic growth' is mentioned 37 times and only twice does the word 'sustainable' appear before it. In stark contrast, sustainable development is only mentioned three times.

Similar statements about how sustainable development has been interpreted as another version of the growth agenda can easily be found from governments in other countries. Here are examples from the US and the UK. Explaining sustainable development, the United States Bureau of Oceans and International Environmental and Scientific Affairs (OES) states 'OES spearheads many partnerships and initiatives that advance our broad development goals of promoting economic growth, social development and environmental stewardship in such areas as forests, water, energy, 
climate, fisheries, and oceans management' (US Department of State n.d., emphasis added). The UK Government 'bases its vision of sustainable development on four broad objectives', one of which is 'Maintenance of high and stable levels of economic growth and employment' (UK Government 2005, emphasis added).

Economic growth remains the policy objective against which all others must be judged, despite statements made by highly placed people in the public and private sectors about balancing economic, social and environmental considerations in decision-making which are seldom acted on in any practical way. Within government, finance trumps environment almost every time. That is why ministers of the environment are considered junior to ministers of finance. That is why the Ministry of Finance in Ontario was able to extricate itself from inclusion under Ontario's path-breaking Environmental Bill of Rights legislation in 1996 (Ligeti 1996). That is why environment departments are the most vulnerable to cuts whenever governments decide they have to trim their budgets as Canadian governments did in the mid-1990s at the federal and provincial levels (Miller 2007), an experience that was replicated in many other countries (Howard 2015; Hook et al. 2011).

Yet not all of the enthusiasm for sustainable development, or sustainability as some prefer to say, is merely economic growth in disguise. There are many who see it as redefining the goals of society at least to include environmental and social considerations on a par with economic. The 'triple bottom line' of economic, environmental and social success and 'stakeholder value' rather than 'shareholder value' favored by some business scholars and writers suggests a broader approach (Elkington 1998). When all three components of the triple bottom line point in the same direction or when serving stakeholders and shareholders are consistent, the way ahead is obvious. But what happens when the economic conflicts with the environmental or the social, or when stakeholder interests conflict with shareholder interests? The financial imperative is very hard to resist and it usually decides the issue.

\subsubsection{The Sustainable Development Goals}

On 25 September 2015, the United Nations General Assembly adopted 'a plan of action for people, planet and prosperity' entitled Transforming our World: the 2030 Agenda for Sustainable Development (United Nations 2015a). The Agenda includes a wide-ranging and candid account of the economic, social and environmental problems confronting different parts of the world. To address these problems the Agenda specifies 17 sustainable development goals supported by 169 targets. The targets are defined 
as 'aspirational and global; with each Government setting its own national targets . . taking into account national circumstances' (United Nations 2015a, p. 13). They build on the previous eight Millennium Development Goals established in 2000, which were partially achieved by the target year of 2015 (United Nations 2015b). It is intended that the sustainable development goals (SDGs) and targets 'will stimulate action over the next 15 years in areas of critical importance for humanity and the planet' (United Nations 2015b, p. 1). The SDGs cannot be faulted for a lack of ambition. Who could fail to be inspired by the resolution:

between now and 2030, to end poverty and hunger everywhere; to combat inequalities within and among countries; to build peaceful, just and inclusive societies; to protect human rights and promote gender equality and the empowerment of women and girls; and to ensure the lasting protection of the planet and its natural resources. (United Nations 2015b, p. 3)

Being 'aspirational', the goals and targets are not legally binding, but nonetheless they are a bold statement of the shared values and objectives of the world's political leaders and have generally been well-received in the media and by the population at large. The issue here is whether and in what ways do they signify a change in the more traditional growth agenda of the UN and its member countries. Here the news is not so good. Economic growth, not just in developing countries, is still regarded as an essential component of sustainable development in the SDGs. Goal number 8 is quite explicit about the importance of economic growth though with the qualification that it be inclusive and sustainable: 'Goal 8: Promote inclusive and sustainable economic growth, employment and decent work for all' (United Nations 2015b, p. 14). Target 8.1 is more precise about the rates of economic growth that are to be achieved between 2015 and 2030 to meet this goal: 'Sustain per capita economic growth in accordance with national circumstances and, in particular, at least 7 per cent gross domestic product growth per annum in the least developed countries' (United Nations 2015b, p. 19).

Target 8.4 recognizes that if economic growth is to be sustainable, it will be necessary for it to be achieved at the same time as pressure on the biosphere is reduced. The target states: 'Improve progressively, through 2030, global resource efficiency in consumption and production and endeavour to decouple economic growth from environmental degradation, in accordance with the 10-Year Framework of Programmes on Sustainable Consumption and Production, with developed countries taking the lead' (United Nations 2015b, p. 19). According to the Framework, 'The most promising strategy for ensuring future prosperity lies in decoupling economic growth from the rising rates of natural resource use and the environ- 
mental impacts that occur in both consumption and production stages of product life cycles' (United Nations 2015c). Unfortunately, the Framework of Programmes on Sustainable Consumption and Development does not include quantitative targets for the rates of decoupling required to make economic growth truly green. We take up this issue in some detail in the next chapter and in later chapters as well. For now, suffice it to say that to achieve absolute reductions in natural resource use and in the waste flows causing environmental impacts, the rate of reduction in these flows must exceed the rate of economic growth by a considerable margin if ambitious targets for absolute reductions are required. It is a leap of faith to believe they can be achieved, not only between 2015 and 2030 but beyond, if economic growth continues at anything like the rates that are hoped for to 2030.

\subsection{ECOLOGICAL MODERNIZATION AND GREEN GROWTH}

The promotion of sustainable development is not the only effort that has been made to find ways of reconciling economic growth with the resource and environmental conditions and limitations of the planet and its various regions. Other well-intentioned efforts along similar lines are 'ecological modernization' and 'green growth'. Ecological modernization refers to the proposition that 'continued industrial development [offers] the best option for escaping from the ecological crises of the developed world' (Fisher and Freudenberg 2001). In other words, economic growth based on the further advancement of technology and industrialization is key to resolving the environmental problems resulting from past technology and industrialization: 'ecological modernization sees environmental protection not as a burden on the economy, but as a "precondition for future sustainable growth"' (Fisher and Freudenberg 2001, p. 703). Ecological modernization is also an agenda for political innovation such that 'the potential for improved ecological outcomes ... is also seen as dependent on changes in the institutional structure of society' (Mol 2000, cited in Fisher and Freudenberg 2001, p. 702).

Green growth, which is closely related to ecological modernization, refers to the belief that the reduction in environmental impact per unit of GDP can outpace growth in GDP so that GDP can grow at the same time as environmental impact declines (OECD 2011a). This is the principle of decoupling, which is integral to all proposals for continuing economic growth and diminishing environmental impact. Green growth is usually promoted as a response to concerns about climate change but can be 
applied to any environmental problem. Indeed, if green growth is not generalizable to all environmental problems, that is a problem in itself since it would mean that economic growth could not continue indefinitely at anything like historical rates without further environmental deterioration. Strong claims have been made for green growth by international organizations such as UNEP (2016b) and the OECD (2011a; 2014; 2015d) and by individual researchers (for example Ekins 2017). We will consider the efficacy of these claims in the next chapter and provide a more comprehensive critique of an influential study on green growth by UNEP in Chapter 7 .

\subsection{CONCLUSION}

In the past two hundred years or so we have seen the idea of economic growth find its way from the minds of some of the most influential writers of the Enlightenment to the top of the list of government policy objectives, in poorer countries where the case for growth is strong, and in rich countries where there is a case to answer. It is this case that we look at in the next few chapters.

\subsection{WHAT COMES NEXT?}

In Chapter 2 we ask the question, why manage without growth? It is there that we introduce the concept of economies as open systems. All systems rely on information. In Chapter 3, we consider the adequacy of prices for conveying accurate and useful information in large and growing economies, particularly with respect to economy-environment interactions, followed in Chapter 4 with a commentary and critique of pricing nature. In Chapters 5,6 and 7 we consider whether economic growth can be sustained for much longer or whether the world's economies are or will be confronting severe constraints as we realize that nature's bounty is being run down, even to the point of exhaustion. The answer to this question provides part of the rationale for entertaining the idea that rich countries, having benefited most from economic growth, should manage without growth to make room for the poorer countries where the case for growth is much stronger.

In Chapter 8 we examine the relationships among the scale (the size of an economy), composition (the goods and services produced and consumed in an economy) and technology, and how they affect the impact of the economy on the environment. This will provide a framework for assessing the potential for decoupling environmental and resource impacts from economic growth on which the promise of green growth depends. We 
will analyze the contribution that slower growth in the rich countries could make to reduce global emissions of greenhouse gases and still leave room for poorer countries to benefit from growth.

What, if any, is the relationship between higher incomes and happiness? We address this question in Chapter 9. It seems that after an income level surpassed by most people in rich countries, relative income influences people's sense of well-being far more than their absolute level of income. Having more counts far less than having 'more than'. Since economic growth cannot make everyone better off in relation to others, it contributes little to increasing happiness. In Chapter 10 we look at how effective economic growth has been in helping countries meet other important objectives. Has it brought full employment? Has it reduced poverty (we know it has not eliminated it)? Has it protected the environment? Can we do just as well without relying on growth? Can we do better? Chapter 11 provides some answers to these questions and in some respects is the most important chapter of the book. It shows that a rich country like Canada can indeed achieve a variety of important objectives, often believed to be attainable only through economic growth, without relying on growth. Rich countries can manage without economic growth and if the arguments of the earlier chapters are sound, the sooner we move in that direction the better. The chapter ends with a consideration of whether the scope of changes required for a viable and desirable future are compatible with the kind of capitalist economy that has evolved over the past few centuries or whether the changes are so significant that they signal the dawn of something new.

In Chapter 12 we look at some policies for managing without growth in rich countries, recognizing that such policies should flow from broad public discussion. The objective in this chapter is simply to seed the discussion, not to complete it.

\section{NOTES}

1. In the election platform of the Liberal party of Canada, which replaced the Conservative government in the general election of 2015, economic growth is mentioned many times and its pursuit is a primary objective of the new government (Liberal Party of Canada 2015). And who can doubt that President Trump's campaign slogan to 'make America great again' was all about faster economic growth?

2. Gross national product (GNP) equals GDP plus net income from abroad.

3. In 2017, the Department of Finance continues to use the definition of sustainable development it introduced in 2007 (Finance Canada 2017). 